\title{
Analysis of Soil Hydraulic Conductivity in Palm Plantations in the Saline Soils of the Oued Rhir
}

\author{
I. CSERNI \\ Kecskemét College, Faculty of Horticulture, Kecskemét (Hungary)
}

Fresh and salt water reserves disposable for irrigation are decreasing on a worldwide scale. Decrease in the amount of salt water suitable for irrigation in the region of the Oued Rhir Valley in Algeria is confirmed by the Étude hydrogéologique (SOGETHA-SOGREAH, 1970) and empirical observations. This is why the rational exploitation of natural artesian salt water needs better consideration.

Irrigation and leaching makes indispensable the renovation of the drain network. To plan the distance drains should be set from each other one must know the hydraulic conductivity of palm-grove soils. In a previous study (CSERNI, 1992) investigations were carried out for the determination of water conductivity.

The aim of the present study was to determine the water conductivity ( $\mathrm{K}$ values) of homogeneous areas in the palm-groves in order to make possible the calculation of drainage parameters.

\section{Material and Methods}

Determinations of hydraulic conductivity factors were carried out for the palm-groves under renovation by SOGETHA-SOGREAH (1970) and CSERNI (1986).

Present investigations took place in autumn 1991. In areas where previous measurements were made (CSERNI, 1986) and in case of soil types with several K-factor determinations from 1986, we sometimes disregarded new measurements, as the previous results gave sufficient information. K-factors had to be determined in all big or important palm-groves. Areas with less favourable draining conditions and soils with weaker productivity were to be considered because their draining conditions could have a significant effect on the area of a

Correspondence to: Dr. Imre CSERNI, Kecskemét College, Faculty of Horticulture, H-6000 Kecskemét, Erdei F. tér 1-3. Hungary. E-mail: cserni@kfk.hu 
palm-grove. K-factors thus describe so-called homogeneous zones (areas and soil types).

The measurements were carried out by the auger-hole method (VAN BEERS, 1970). Following the boring of the generally $1.5-2 \mathrm{~m}$ deep hole, a perforated cylinder was placed into it to prevent falling in.

Before starting the measurement we defined whether the groundwater table was under pressure or not. We waited for the establishment of the resting water level. Water was removed from the hole several times and measurements were carried out three times. Results were recorded in a protocol.

Reflow of the water into the bored hole was taken into account only in the range of $0.2-0.4 \mathrm{~m}$ above the groundwater table level. K-factor values were calculated according to VAN BEERS (1970). The mean of the three calculations was given as the end result for the K-factors.

Soils are groupped according to the FAO classification system (FAO, 1998). Water conductivity was classified according to EGGELSMANN (1973).

\section{Results and Discussion}

K-factors (hydraulic conductivity), qualification of the soils on the basis of this factor and drainable porosity of different soil types are presented in Table 1.

$\mathrm{K}$-factors representative of the original areas are significantly modified by the maintenance of the drainage systems, systematic irrigations, leaching, cultivation and filling up with sand. Part of the roots get into the upper layer of the soil as a result of filling up with sand. Soil porosity thus increases, leading to the further development of roots and an increase in permeability. Systemic irrigation and drainage on these areas prevents secondary alkalinization and increases leaching, leading to the rise of the $\mathrm{K}$-factor in the upper soil layers. In soils containing a high amount of gypsum its solution should also be accounted for.

In most sandy and hydromorphic soils containing gypsum in a crystallized form, the K-factor was extremely high. In hydromorphic soils where the "gley" and "pseudogley" was near to the surface, the water conductivity was still very high. Where gley occurred in the lower horizons, the K-factor decreased and in some cases hardly exceeded the medium level $(\mathrm{K}=0.46 \mathrm{~m} / \mathrm{d})$. In cases when the gley was present only in a thin layer, occasionally very high $\mathrm{K}$-values were recorded.

Crust and formation of crust had no significant effect on permeability. Crusts did not influence the K-factor values in deeper horizons either. A high amount of gypsum had a favourable effect, as it inhibits the impairment caused by sodium salts (SOGETHA-SOGEAH, 1970 CSERNI, 1986). Crusts were already broken up during plantation and the irrigation enhanced the solution of saline 
Table 1

K-factors (hydraulic conductivity), qualification of the soils on the basis of this factor and drainable porosity of different soil types

\begin{tabular}{|c|c|c|c|}
\hline $\begin{array}{l}\text { Soils according to the } \\
\text { FAO classification }\end{array}$ & $\begin{array}{l}\text { K-factors (m/d) } \\
\text { "Hydraulic } \\
\text { conductivity" }\end{array}$ & $\begin{array}{l}\text { Qualification of } \\
\text { soils based on K- } \\
\text { factors by EGGELS- } \\
\text { MANN (1973) }\end{array}$ & $\begin{array}{c}\text { Drainable } \\
\text { porosity } \\
\%\end{array}$ \\
\hline Arenosols & $1.71->4.00$ & $\begin{array}{c}\text { very or extremely } \\
\text { high }\end{array}$ & $13.2->20.0$ \\
\hline $\begin{array}{l}\text { Solonchaks with gley } \\
\text { less deep } \\
\text { deep } \\
\text { with pseudogley on the } \\
\text { surface }\end{array}$ & $\begin{array}{c}\text { mean }=1.94 \\
0.46-1.54 \\
1.06-1.98\end{array}$ & $\begin{array}{l}\text { very high } \\
\text { high or very high } \\
\text { very high }\end{array}$ & $\begin{array}{c}13.9 \\
6.8-12.4 \\
10.3-14.1\end{array}$ \\
\hline $\begin{array}{l}\text { Gypsisols } \\
\text { with crust } \\
\text { from } 0.3 \text { to } 0.7 \mathrm{~m} \\
\text { from } 0.7 \text { to } 1.2 \mathrm{~m} \\
\text { with formation of crust } \\
\text { from } 0.3 \text { to } 0.7 \mathrm{~m} \\
\text { from } 0.7 \text { to } 1.2 \mathrm{~m} \\
\text { mottled } \\
\text { crystals }\end{array}$ & $\begin{array}{c}1.12-2.11 \\
2.87 \\
\\
2.28-2.71 \\
0.55 \\
0.33-0.93 \\
2.01->4.00\end{array}$ & $\begin{array}{c}\text { very high } \\
\text { extremely high } \\
\text { very or extremely } \\
\text { high } \\
\text { high or very high } \\
\text { medium or high } \\
\text { very or extremely } \\
\text { high }\end{array}$ & $\begin{array}{c}10.6-14.5 \\
16.9 \\
15.1-16.5 \\
7.4 \\
5.7-9.6 \\
14.2->20.0\end{array}$ \\
\hline
\end{tabular}

crusts and crystallized gypsum. By this way water moves in these soils like in communication vessels. The formation of crust, in deeper levels, decreased water conductivity $(\mathrm{K}=0.45 \mathrm{~m} / \mathrm{d})$.

The lowest hydraulic conductivity value occurred when gypsum was coherent, cemented $(\mathrm{K}=0.33 \mathrm{~m} / \mathrm{d})$.

$\mathrm{K}$-factors were representative of main soil types and individual palm-grove areas. Due to this fact we could apply the same results for other similar palmgroves.

\section{Agronomical Aspects}

The traditional growing of nitrogen-fixing perennial legumes (alfalfa, Egyptian clover, melilot, etc) in palm-groves is essential in addition to date production.

Systemic flooding irrigation decreases the salt content of soils, increases the yields of date and legumes. 
By their root-system legumes improve the nitrogen balance, structure and water drainage of soils.

The green parts of the cultivated legumes serve as fodder for animals (goats, sheep, cows), which turn it to manure. This manure increases the nutrient supply of the soils for palm-trees and vegetables. The positive results of stubble and root manuring (green manuring) of legumes are also confirmed by experiments on sandy soils (BAUER \& CSERNI, 1984a,b). The elaboration of a good rotation is possible. At last dates and vegetables produced in this way could be sold better on the markets as bioproducts.

\section{Summary}

The aim of the study was to determine K-factors of homogeneous zones in palm-groves in order to make possible the interpolation of these values to other similar areas, and by this way to help the calculation of draining parameters. Another goal was to interpret the agronomical aspects of the results.

Investigations for the determination of conductivity factors (K-factors) were carried out in the palm-groves of the Oued Rhir Valley. The measurements - conducted three times - were made by the auger-hole method. After boring the hole, a perforated cylinder was placed into it to prevent falling in. K-factor values were calculated after van Beers. The mean of the three calculations was given as the end result for the $\mathrm{K}$-factors.

Our results show that K-factor values are influenced by the porosity, type, bulk density and texture of soils, their salt content and the form of gypsum. The $\mathrm{K}$-factor was extremely high in case of sandy soils and soils containing crystallized gypsum. Water conductivity was moderate in case gley and pseudogley were located in deeper layers. The lowest values occurred when gypsum was found in cemented coherent particles. Salinization in deeper layers influenced hydraulic conductivity only in case it was associated with finer texture and airless layers.

Besides date production, the traditional growing of nitrogen-fixing perennial legumes (alfalfa, Egyptian clover, melilot, etc.) in palm-groves is essential. Systemic flooding irrigation decreases the salt content of soils, increases date and legumes yields. Legumes - by their root-system - improve the nitrogen balance, structure and water drainage of soils. The green parts of the cultivated legumes serve as fodder for animals (goats, sheep, cows), which turn it to manure. This manure increases the nutrient supply of the soils for palm-trees and vegetables. The positive results of stubble and root manuring (green manuring) of legumes is also confirmed by experiments on sandy soils. The elaboration of a good plant rotation is possible. At last, date and vegetables produced in this way could be sold better on the world market as bioproducts. 
Key words: bulk density, hydraulic conductivity, palm-grove, root manuring, salinization

\section{References}

BAUER, F. \& CSERNI, I., 1984a. Placing of phosphorus fertilizer in hairy vetch-rye crop rotation on cover sandsoil in the Danube-Tisza Midregion. (In Hungarian) Növénytermelés. 33. 49-65.

BAUER, F. \& CSERNI, I., 1984b. Placing of phosphorus fertilizer in melilot crop rotation on cover sand soil in the Danube-Tisza Midregion. (In Hungarian) Növénytermelés. 33. 535-547.

CSERNI, I., 1986. Réaménagement et extension des palmeries de l'Oued Rhir. Étude agro-pédologique. Mission C. Ressources en sol. TESCO-VIZITERV. Budapest. (Manuscript)

CSERNI, I., 1992. Actualisation de l'étude du réaménagement et de l'extrension des palmeraies vallées haute et basse de l'Oued Rhir. TESCO-VIZITERV. Budapest. (Manuscript)

EgGelsmann, R., 1973. Dränanleitung. Verl. Wasser und Boden. Hamburg.

FAO, 1998. World Reference Base for Soil Resources. World Soil Resources Reports 84. FAO. Rome.

SogethA-SogreAH., 1970. Participation à la mise en valuer de l'Oued Rhir. Etude agro-pédologique. (Manuscript)

VAn BeERS, W. F. J., 1970. The Auger Hole Method. ILRI Bulletin. No. 1. Wageningen. 